\title{
과학기술혁신과 ODA
}

\section{목 차}

I. 서론

II. 선행연구

III. KOICA의 과학기술혁신 ODA 전략

IV. 지속가능발전목표와 과학기술혁신 ODA

\section{참고문헌}

\section{I. 서론}

본 연구는 제 29 회 개발협력포럼에서 과학기술혁신 세션에서 논의되었던 KOICA의 과학기술 ODA 협력전략에 대한 발표와 논의 내용을 다루고 이러한 KOICA의 과학기술 ODA 전략에 대하여 과학기 술 국제협력 관점에서의 그 중요성과 협력가능성을 다루는데 주안점을 두고 있다.

개발협력 ODA관점에서 과학기술혁신의 중요성이 대외적으로 높아지면서 $\mathrm{KOICA}$ 실행체계에서 기술총괄팀이 새로 발족되고 이에 따른 과학기술혁신 ODA 전략을 수립하게 된 것은 국제사회에서의 방향이나 우리나라의 역량적 측면을 보았을 때 매우 바람직한 현상이라고 볼 수 있다. 개발협력이 주 로 경제적 측면과 산업적 측면을 중심으로 환경이나 보건, 교육 등의 분야별로 개발협력사업들이 이 루어지고 있는 상황에서 전체적인 경제, 산업, 환경, 사회적 이슈들을 관통하는 과학기술혁신의 주류 화에 대해서 논의하고 이를 바탕으로 과학기술혁신활동을 수행하는 공공 및 민간부문과의 협력가능성 등을 논의하는 것은 시의적절하고 필요한 내용이라고 할 수 있다. 
본 연구에서는 개발협력포럼에서 KOICA가 발표한 과학기술혁신 ODA 전략에 대해서 살펴보고 이 러한 과학기술혁신 ODA전략이 2015년 UN개발정상회의에서 채택된 지속가능발전목표와의 연관성과 맥락이 무엇이며 기존에 과학기술 국제협력 사업이나 연구개발 프로그램을 통해서 진행되어 온 사항 들과 연계성을 어떻게 찾아나갈지에 대해서 고민해 보고자 한다.

특별히 UN지속가능발전목표들은 기존의 개발협력의 원조관점에서 탈피하여 지구 공동체적인 글 로벌 이슈의 공동해결이라는 관점에서 개발협력을 논의하는 파트너십을 강조하고 있기 때문에 개발도 상국들의 대응역량강화를 위한 과학기술혁신 $\mathrm{ODA}$ 는 매우 중요한 역할을 하게 될 것으로 기대되고 있 다. 또한 $\mathrm{KOICA}$ 에서는 적정기술을 통한 개발협력사업들에 대해서 오랫동안 연구를 진행해왔으며 과 학기술부문에서는 과학기술 국제협력의 관점에서 개발도상국가와의 협력사업에 대해서 오랫동안 연 구를 진행해 왔기 때문에 이러한 상호 연구의 접점으로서 개발협력과 과학기술협력이 상호 연계될 수 있는 부분에 대해서 논의하고자 한다.

제 2 장에서는 기존의 선행연구들을 과학기술협력 관점과 개발협력의 관점에서 간략하게 살펴보고 제3장에서는 $\mathrm{KOICA}$ 에서 추구하고 있는 과학기술혁신 개발협력 전략에 대해서 논의하고 제4장에서 는 UN의 지속가능발전목표가 과학기술혁신과 어떻게 연계되는지 살펴보고 이에 대해서 과학기술 국 제협력과 $\mathrm{R} \& \mathrm{D}$ 프로그램 관점에서의 연관성에 대해서 살펴본다. 마지막으로 결론에서는 향후의 협력 방안과 제언에 대해서 제시한다.

\section{II. 선행연구}

과학기술혁신 개발협력과 관련하여 기존의 선행연구들은 많지 않다. 우리나라에서는 과학기술정 책연구원에서 과학기술외교와 관련한 과제들을 지속적으로 추진해왔다. 이명진 외(2014)에서는 박 근혜 정부가 추진하고 있는 창조경제의 글로벌화가 필요한 이론적 근거에 대한 연구와 더불어 창조 경제의 글로벌화를 위한 효과적인 방안으로서 글로벌 거점센터 구축을 제시하였다. 여기에서는 글로 벌 개방 혁신과 글로벌 가치사슬, 플랫폼의 이론적 고찰과 더불어 해외 과학기술혁신 현지거점 사례, 해외 혁신 플랫폼 구축 사례 등을 제시하고 과학기술외교 사업의 일환으로 적정기술센터 사업 및 글 로벌 과학기술혁신 플랫폼 구축 방안을 제시하였다. 홍성범 외(2013)의 연구에서는 청색경제(Blue Economy)의 부상과 과학기술외교의 효율적 대응전략에 대한 연구를 통해서 청색경제의 부상과 국 제과학기술 환경변화에 따른 새로운 청색경제 협력 거버넌스에 직 · 간접적으로 영향을 미칠 수 있는 과학기술외교 · 협력과제를 발굴하는 한편 이의 실현을 위한 전략 제시하고자 하였다. 과학기술외교 
와 관련한 이론적 프레임워크를 바탕으로 과학기술을 활용한 경제영토, 안보, 자원, 국제적 리더십 확 보 외교, 즉 외교를 위한 과학기술 유형 및 각 경제영역별 소수 다자 협력체 진입을 위한 다자 외교, 즉 외교속의 과학기술 차원의 과학기술외교(우주응용 및 우주탐사), 그리고 북극해-다자협력에서 양 자협력 중심으로(과학기술을 위한 외교 및 외교를 위한 과학기술강화)를 제안하고 있다. 장용석 외 (2012) 연구에서는 스마트파워를 갖춘 글로벌 뉴리더로서 한국의 과학기술외교 종합 전략을 모색하 고 있다. 즉 스마트파워에 기반한 대 선진국, 신흥국, 개도국 및 다자간 과학기술외교 전략을 모색하 고 이를 위한 정책과제들을 도출하고자 하였다. 이를 위해서 스마트파워 기반 과학기술외교의 개념틀 을 개발하고 대 선진국, 대 신흥국, 대 개도국 및 다자 과학기술외교 전략을 제시하고 있다. 이들 연구 결과들에서는 과학기술 외교전략을 외교를 위한 과학기술협력, 과학기술을 위한 외교협력, 다자기구 속의 과학기술외교로 구분하고 글로벌 창업경제의 확산이나 청색경제, 혹은 개발협력전략 차원에서 논의를 하고 있다. 이는 전통적 차원에서 선진국으로부터의 과학기술을 이전받기 위한 외교적 차원의 노력에서 국제기구에서의 과학기술논의의 확대에 발맞추어 과학기술을 활용한 다자기구에서의 외교 적 확대, 그리고 개발도상국가의 경제발전과 산업발전, 과학기술 혁신 시스템 발전을 돕기 위한 외교 적 차원에서 과학기술을 활용하는 방안에 대한 논의들이 그것이다. 보고서들에서는 외교적 관점에서 과학기술의 중요성이 높아지는 가운데 우리나라가 과학기술을 활용한 외교적 차원의 활동 강화가 기 존의 기술이전을 위한 목적으로 외교를 활용하는 측면보다 중요해지고 있으며 이를 위한 개발도상국 가에 대한 과학기술혁신 ODA 사업이 중요하다는 점을 강조하고 있다.

과학기술 ODA에 대해서 본격적으로 연구한 내용들 가운데 초기의 연구는 이우성 외(2010)의 연 구가 있다. 이는 지속가능발전과 관련한 경제적, 사회적, 환경적 지속가능성과 과학기술혁신의 연계 성을 가지고 개발도상국가(캄보디아, 베트남, 필리핀)에서의 과학기술 ODA 사업 가능성에 대해서 현 지 현황분석과 진단을 통해 사업 아젠다를 제안하였다. 교육과학기술부는 2011년 "개도국의 역량개발 및 지속가능한 발전을 지원하기 위한 교육과학기술 공적개발원조 선진화 방안"을 발표하였다. 정책방 안에서는 중점추진과제로 1. 공적개발원조 확대 및 전략적 지원 강화, 2. 한국형 공적개발원조를 통한 개도국 역량개발, 3. 공적개발원조 선진화를 통한 원조효과성 제고, 4. 교육과학기술 공적개발원조 추진기반 마련 등을 제시하고 있다. 총리실 주관으로 시행한 경제인문사회연구회에서는 2012년 미래 사회 협동연구로 '한국형 ODA 모델 수립'을 제안하였다. 특별히 한국형ODA 모델 가운데 과학기술모 델로서 1. 과학기술진흥을 위한 행정체계 구축 프로그램, 2. KIST 설립/운영 시스템 구축 프로그램, 3. 경제성장 기반구축을 위한 기업의 자생적 연구환경 조성 프로그램, 4. 적정과학기술 지원 등 19 개 모델을 대표모델로서 제안하고 있다. 이우성 외(2013) 연구에서는 ‘한국형 과학기술 ODA 로드맵’ 정 책연구를 통해서 우리나라가 추진해야하는 과학기술 ODA 로드맵에 대해서 제안하고 있다. 여기에서 는 과학기술 $\mathrm{ODA}$ 의 개념과 범위를 제안하고 이에 따른 과학기술 $\mathrm{ODA}$ 의 규모와 분석을 제시하고 중 
점 추진과제로서 1. 지속 가능한 과학기술 ODA 추진체계 정립, 2. 적정과학기술 지원 등 상생발전형 $\mathrm{ODA}$ 확대, 3. 개도국 과학기술 지원사업 개선 및 확대, 4. 개도국 과학기술 연구센터/연구원 설립 및 연구역량강화지원, 5 . 과학기술단지/혁신클러스터 설립지원 등을 제안하고 있다.

이러한 관점들의 연구는 과학기술부문과 외교부문에서 제안하고 고민하는 과학기술ODA 협력전략 에 대한 정책연구와 현황분석 연구들이지만 개발협력부문의 관점에서의 정책방안 마련은 아직까지 이 루어지지 못하였으며 이번에 KOICA가 개발협력포럼에서 발표한 내용이 그 초안이다.

\section{KOICA의 과학기술혁신 ODA 전략}

KOICA의 기술총괄팀은 제29차 개발협력포럼에서 “Mainstreaming STI in KOICA's ODA: Opportunities and Challenges"이라는 제목으로 KOICA가 계획하고 있는 과학기술혁신ODA 전략 에 대해서 발표하였다. 제목에서 나타나듯이 KOICA는 과학기술 ODA가 Cross-Cutting하는 이슈이 며 전반적인 ODA사업에 있어서 과학기술혁신이 주류화될 필요성에 대해서 인식하면서 과학기술혁신 $\mathrm{ODA}$ 전략을 발표하였다.

과학기술혁신(Science, Technology and Innovation, STI) ODA에 대해서 새로운 전략을 수립하 게 된 배경에 대해서 설명하면서 기회적 요인과 도전적 상황에 대해서 설명하고 있다. 과학기술혁신 $\mathrm{ODA}$ 의 중요성이 높아지는 가장 중요한 이유는 2015년 UN개발정상회의에서 채택된 지속가능발전목 표(Sustainable Development Goals, SDGs)에 기인한다고 볼 수 있다. 지속가능발전목표는 전지구 적인 경제적, 사회적, 환경적, 평화적 이슈들에 대해서 다루면서 과학기술혁신의 중요성에 대해서 인 식하고 그 기반을 두고 있기 때문에 지속가능발전을 위한 과학기술혁신의 중요성이 개발원조에 있어 서도 중요한 아젠다로 부상하고 있다는 지적이다.

우리나라의 역량 측면에서도 과학기술혁신 ODA는 중요성을 갖는다. 한국은 고도 성장기에 과학 기술혁신을 통한 산업발전과 산업고도화의 모범적 사례를 가지고 있으며 이러한 성장초기부터의 과 학기술혁신에 대한 투자경험은 개발도상국가와의 개발원조에 있어서 중요한 개발경험 공유의 자산 이 된다고 할 수 있다. 우리나라의 역량 차원의 연장선상에서 우리나라는 과학기술혁신 시스템을 발 전시켜온 중요한 기관들과 전문가들이 광범위하게 분포하고 있다는 점이다. 이들 정부출연연구소, 대학, 혁신적인 민간기업 부문 등의 공공과 민간부문을 포괄하는 중요한 과학기술혁신 관련 기관들 은 개발원조에 있어서 개발협력의 파트너로서의 역할을 감당할 수 있는 우리나라의 중요한 역량이라 고 할 수 있다. 
이는 대내외적인 측면에서 모두 우리나라가 과학기술혁신 $\mathrm{ODA}$ 를 추진하기에 중요한 위치에 있다 는 점을 보여준다. 국제사회에서는 지속가능발전목표와 과학기술혁신의 역할이 중요하여진 것과 더 불어 우리나라는 국제사회에서 과학기술 기반의 경제성장을 이룬 국가로서의 높은 평가를 받고 있다. 더불어 국내에서는 이러한 과학기술혁신 기반의 산업발전, 경제성장을 이룬 전문적 역량의 기관들과 전문가들이 포진해 있으며 이들이 개발협력을 적극적으로 수행하고자 하는 의지를 가지고 있다는 점 이 중요한 기반이라고 할 수 있다.

그러나 $\mathrm{KOICA}$ 에서는 이러한 과학기술혁신 $\mathrm{ODA}$ 를 추진하기 위해서 넘어서야할 몇 가지 장애요인 들이 있음을 지적하고 있다. $\mathrm{KOICA}$ 에서 제시한 과학기술혁신 ODA 실행에 있어서의 장애요인은 대 부분 기존에 이러한 형태의 $\mathrm{ODA}$ 사업에 대한 경험과 지식이 부족하다는 점을 지적하고 있다. 기반적 으로는 $\mathrm{ODA}$ 분류체계에서 과학기술혁신 ODA에 대한 분류체계가 따로 존재하지 않으므로 인해서 과 학기술혁신 $\mathrm{ODA}$ 에 대한 정의에서부터 분류와 적용에 이르기까지 다양한 해석이 가능하고 이에 따라 정책적 개입이 쉽지 않다는 문제점이 있을 수 있다. 연관되어서 과학기술혁신 ODA 사업에 대해서 선 진국과 신흥공여국 공히 이 영역에 대한 사업경험과 더불어 이론적인 배경과 지식축적이 많지 않다는 점이다. $\mathrm{ODA}$ 영역에 있어서 과학기술혁신은 새로운 영역의 등장이라고도 볼 수 있는 것이다.

과학기술 국제협력은 과학기술혁신 ODA와는 다르게 이미 과학기술계 내에서 상당히 오랫동안 경 험을 축적해온 영역이지만 이러한 과학기술 국제협력이 ODA라고 하는 개발협력 영역과 융합되어서 진행되어 오지 못했다. 따라서 실상 과학기술 국제협력과 산업과 무역협력, 국제 개발협력 영역이 상 호 어떻게 협력해나가야 할 것인가에 대한 논의는 향후 $\mathrm{KOICA}$ 와 더불어 국제사회가 풀어나가야할 매우 중요한 과제라고 할 수 있다. 우리나라의 ODA 측면에서도 과학기술혁신 ODA전략은 매우 초기 의 논의이기 때문에 이를 실행할 수 있는 실행체계와 협력전략에 대한 논의는 성공을 위한 매우 중요 한 요인이라고 할 수 있다.

마지막으로 과학기술혁신 ODA전략에 있어서 빈곤문제 해결을 논할 때 빠질 수 없는 논의가 적정 기술에 대한 논의인데 주지하다시피 1960년대부터 논의되어온 적정기술과 빈곤문제해결이 아직까지 뚜렷하게 제시할 수 있는 성공적 사례들이 많지 않다는 점은 과학기술혁신 ODA를 추진하는데 있어서 진지하게 고민하고 그 실패요인이 무엇이며 지속가능한 빈곤문제해결로서의 적정기술혁신을 어떻게 바라보아야 하는지에 대한 심도 있는 논의가 필요하다고 할 수 있다.

이러한 문제의식 하에서 $\mathrm{KOICA}$ 가 과학기술혁신 $\mathrm{ODA}$ 를 추진하고자 하는 전략들과 정책과제들에 대한 제언들을 제시하였다. $\mathrm{KOICA}$ 의 과학기술혁신 $\mathrm{ODA}$ 는 크게 3 가지 방향성을 가지고 있다. 이는 1) 과학기술을 통한 문제해결방식을 $\mathrm{KOICA}$ 의 개발협력 프로젝트에서 주류화하는 통합화 정책, 2) 개 발협력의 대상 파트너 국가들의 혁신시스템을 강화하는 과학기술혁신 기반구축정책, 3) 민간부문의 
과학기술혁신역량을 활용한 기술기반의 혁신 ODA 정책들이라고 할 수 있다.

1) 과학기술혁신 주류화 통합화 정책에서는 현재 존재하는 개발협력 프로젝트와 프로그램들에서 과학기술적 해결책들을 적절하게 효과적으로 활용할 수 있도록 하며 현장학습(Learning by Doing) 에 의한 기술이전 활동을 촉진하기 위한 정책을 의미한다. 이는 기존의 식수공급사업이나 태양광 등 신재생에너지 공급사업에 지식이전과 역량강화를 보다 적극적으로 수행하는 것을 포함한다고 지적한 다. 이는 농업, 폐기물관리, 보건의료, 수자원, 에너지 등 기존의 대부분의 사업들에서 과학적 연구와 기술지식의 이전을 통한 역량강화 측면이 중요한 사업들에 과학기술의 역할을 강화하겠다라는 의미로 보여진다.

2) 개발협력 대상국가들의 혁신시스템을 강화하는 기반구축정책은 개발도상국가들이 자생적으로 지속가능한 혁신시스템을 조성하고 만들어갈 수 있도록 과학적 기반과 기술을 통한 상업화 시스템의 조성에 KOICA가 ODA 사업을 통해서 지원하겠다는 의미를 갖고 있다. 여기에는 개발도상국들의 연 구기관과 대학의 연구기능을 강화해주고 개발도상국들에서의 산학연 협력을 통한 기술 상용화를 지 원해주며 혁신클러스터와 테크노파크와 같은 지역혁신전략의 수립에 기여하고, 과학기술 분야들에서 의 인적자원의 개발을 지원하는 등의 역할을 강화하겠다는 방향성을 제시하고 있다. 기존에 진행되고 있는 유사한 사례로는 베트남에 추진되고 있는 V-KIST 연구원 설립사업과 개발도상국가의 대학내의 연구개발 센터의 설립과 연구역량강화 지원사업들이 이에 해당된다고 할 수 있다.

3) 마지막은 정책방향성은 빈곤계층에서의 시장창출을 위한 혁신 ODA 사업이라고 할 수 있다. 이 는 민간부문의 기술기반 혁신역량을 바탕으로 개발도상국들의 BoP(Bottom of Pyramid) 시장에서 의 민간시장활성화를 촉진하는데 기여하는 민관협력사업( $\mathrm{PPP}($ Public-Private Partnership))으로서 의 창의적 혁신사업을 의미한다. 그리고 이러한 창의적 혁신사업들의 결과물들을 사회적기업과 민간 부문을 통해서 확산할 수 있는 사업들을 촉진하고자 하는 것을 의미한다. 이러한 사업의 사례들은 기 존에 NGOs와 대학, 기업의 CSR과의 협력을 통해서 PPP 사업으로 추진되었던 적정기술사업이나, 신 재생에너지, 농업기술 사업 등이 이에 해당된다고 할 수 있다. 그리고 2015년도에 처음으로 추진되고 있는 창의적 기술 솔루션 프로그램이 $\mathrm{BOP}$ 시장을 향한 창의적이고 혁신적인 제품과 서비스 창출을 통한 빈곤문제해결 사업의 핵심이라고 할 수 있다.

$\mathrm{KOICA}$ 는 현재 포용적 혁신 프로그램의 핵심적인 사업으로서 창의적 기술 솔루션 프로그램 (Creative Technology Solution Program)을 2015년에 처음 출범시키고 사업을 진행하고 있다. 기 술개발의 측면에서는 개발도상국가의 빈곤층에 맞는 적정기술과 더불어 창의적이고 혁신적인 첨단 기술들을 가지고 창의적 기술 솔루션이라고 하는 비즈니스 모델의 개발을 통해서 시범사업을 추진하 고 이러한 사업의 성공을 기반으로 국가적인 스케일업(scale-up) 사업이나 사회, 경제적 개발협력사 
업과의 연계사업을 추진하는 장기적인 계획을 보여주고 있다. 이는 혁신적인 기술 솔루션을 기반으로 한 기업가정신을 통해서 개발도상국들의 $\mathrm{BOP}$ 계층들에게 사회적 혁신을 활성화하는 것을 그 목적으 로 하고 있다(〈그림 1〉참조).

\section{〈그림 1〉 KOICA의 창의적 기술 솔루션 프로그램}

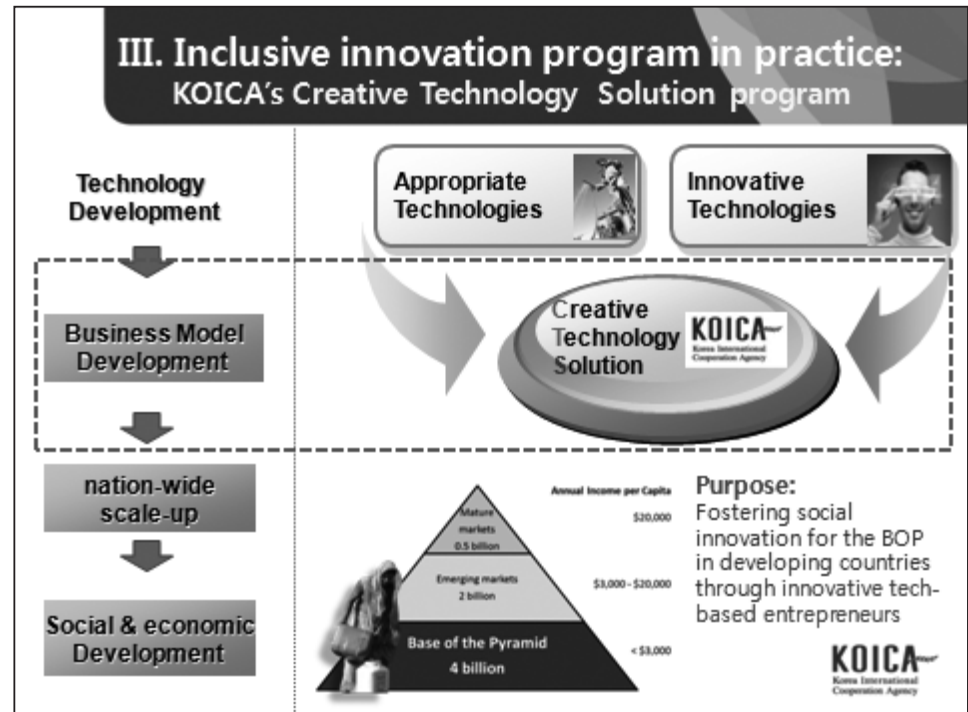

출처: KOICA(2015) “Mainstreaming STI in KOICA'S ODA" 29차 개발협력포럼

이러한 과학기술혁신 ODA사업전략과 과제들을 통해서 KOICA가 진행하고자 하는 과학기술혁신 $\mathrm{ODA}$ 의 방향성과 지향점은 아래와 같이 요약되어서 제시되었다. 1) 과학기술부문과 개발협력부문, 민 간산업부문간의 지식공유를 통한 개발협력의 효과성 제고, 2) 개발도상국가의 산업발전이 혁신역량의 강화와 연계될 수 있도록 하는 혁신역량 제고, 3) 개발도상국가의 발전에 있어서 '성장을 위한 혁신'과 포용적 발전을 위한 '포용적 혁신'간의 균형 잡힌 접근을 강조하는 균형성장 제고, 4) 기존 산업발전만 이 아닌 새로운 기업가정신의 발현을 통한 기술창업과 민간의 혁신활동을 촉진하는 혁신적 접근법 제 고, 5) 개발협력현장에서 도출되는 우수사례들과 신제품 프로토 타입들이 검증되고 피드백되면서 선 순환적과 지속가능할 수 있도록 하는 혁신확산의 제고 등이라고 할 수 있다.

외교부에서 추진하고 있는 개발협력 ODA 사업의 중점사업으로서 과학기술혁신 ODA 사업이 5 가 지 중점추진사업방향가운데 하나로서 제시되고 있다는 점에서 과학기술혁신 ODA는 우리나라가 추구 할 수 있는 개발협력의 새로운 혁신적인 방안이라고 보여지며 이러한 과학기술혁신 ODA 방안들의 성 
공적인 실행을 위해서 다양한 이해관계자들과 주체들간의 협력적 거버넌스 형성과 실행이 중요한 관 건이라고 보여진다.

\section{IV. 지속가능발전목표와 과학기술혁신 ODA}

2015년 UN 개발정상회의에서 17 가지 지속가능발전목표가 채택된 것은 국제사회의 논의가 개발도 상국가에 대한 선진국의 개발원조에 대한 논의보다 훨씬 포괄적으로 진전되어 미래 지구환경적 변화 에 대응하기 위한 선진국과 개발도상국을 포함하는 글로벌 국제사회차원에서의 협력방안과 대응방안 에 대한 논의로 발전된 것이라고 볼 수 있다.

글로벌 사회가 경제적, 환경적, 사회적, 평화적 측면에서의 지속가능성을 논의하고 이에 대한 목표 를 설정한 것은 현재의 글로벌사회의 위기가 더 이상 지속가능하지 않은 미래를 나을 수 있다는 인식 에서 비롯되고 있으며 이러한 관점에서 개발협력원조의 관점도 변화하고 있다는 점을 인식해야한다. 이는 과거의 개발협력원조가 개발도상국가의 경제발전을 돕는다는 호혜적 관점에서 머물렀다고 한다 면 이제는 지구의 지속가능발전을 위해서는 선진국들의 지속가능발전 목표의 달성과 더불어 개발도상 국들이 지속가능발전을 달성할 수 있도록 해야 한다는 공존에 대한 위기의 관점에서 개발협력이 이루 어진다는 점이다. 글로벌 사회의 경제적 불균형, 사회적 불안정, 환경적 위기, 평화안보의 위협은 이 제 개별 국가차원의 문제와 도전을 넘어서 글로벌 도전과제로서 선진국과 개발도상국가가 공동 대처 할 수 있는 역량이 갖추어져야 한다는 것을 의미한다.

이러한 관점에서 개발도상국가가 가지고 있던 가장 취약한 역량가운데 하나라고 할 수 있는, 그리 고 가장 뛰어넘기 어려운 역량가운데 하나라고 할 수 있는 과학기술혁신 역량을 구축하고 글로벌 도 전과제에 공동으로 대처하기 위한 개발도상국가에 대한 과학기술혁신 ODA 사업은 이러한 시대적 관 점에서 매우 중요한 역할과 과제를 안고 있다고 할 수 있다.

$\mathrm{UN}$ 개발정상회의에서 채택된 지속가능발전목표에서는 17 가지 목표들 대부분에서 과학, 기술, 연 구, 혁신 등의 단어들이 포함되면서 개별 목표들에서 과학기술혁신이 그 기반으로서 차지하는 역할의 중요성을 보여주고 있다(〈표 1〉참조). 
〈표 1〉 지속가능발전목표와 과학기술혁신 연계

\begin{tabular}{|c|c|c|c|}
\hline 목표 & 분야 & 번호 & 내용 \\
\hline G1. & 빈곤 & 1.4 & appropriate new technology(적정기술) \\
\hline G2. & 식량/영양/농업 & 2.a. & $\begin{array}{l}\text { 개도국, 특히 저개발국가의 농업생산역량 확대를 위하여 국제협력을 통한 농 } \\
\text { 업연구와 기술개발에 대한 투자 확대 }\end{array}$ \\
\hline G3. & 보건 & 3.b. & $\begin{array}{l}\text { 개도국에 주로 영향을 미치는 질병들에 대한 백신과 치료제 연구개발에 대한 } \\
\text { 지원 }\end{array}$ \\
\hline G4. & 교육/평생교육 & 4.b. & $\begin{array}{l}\text { 개도국과 저개발국가에 고등교육(ICT, 엔지니어링과 과학프로그램을 포함하 } \\
\text { 는)에 있어서 선진국, 여타 개도국에서 공부할 수 있는 장학금의 증대 }\end{array}$ \\
\hline G5. & 양성평등/여성 & 5.b. & $\begin{array}{l}\text { 여성의 역량강화를 위하여 enabling technology, 특별히 ICT 기술의 사용을 } \\
\text { 강화 }\end{array}$ \\
\hline G6. & 물/위생 & 6.a. & $\begin{array}{l}\text { 개도국에서의 물과 위생과 관련한 활동과 프로그램들을 위한 국제협력과 역 } \\
\text { 량강화를 지원하는데 이는 물 관련 기술들 포함 }\end{array}$ \\
\hline \multirow[t]{2}{*}{ G7. } & \multirow[t]{2}{*}{ 에너지 } & 7.a. & $\begin{array}{l}\text { 청정에너지 연구와 기술들(신재생에너지, 에너지 효율성, 청정화석연료기술 } \\
\text { 등)에 대한 접근성을 강화하기 위한 국제협력을 촉진하고 에너지 인프라와 } \\
\text { 청정에너지 기술에 대한 투자촉진 }\end{array}$ \\
\hline & & 7.b. & $\begin{array}{l}\text { 개도국과 저개발국가에서의 현대적이고 지속가능한 에너지 서비스들을 위한 } \\
\text { 인프라를 확대하고 기술을 업그레이드 }\end{array}$ \\
\hline \multirow{2}{*}{ G8. } & \multirow{2}{*}{$\begin{array}{l}\text { 경제성장/ } \\
\text { 일자리창출 }\end{array}$} & 8.2 & 기술적 업그레이드와 혁신을 통한 경제적 생산성 증대 \\
\hline & & 8.3. & 기업가정신과 창의성, 혁신을 지원하는 개발 지향적 정책들의 촉진 \\
\hline \multirow{5}{*}{ G9. } & \multirow{5}{*}{$\begin{array}{l}\text { 산업화/혁신을 } \\
\text { 위한 인프라 }\end{array}$} & 9.4 & 환경 친화적인 기술들과 산업과정 채택의 증대 \\
\hline & & 9.5 & $\begin{array}{l}\mathrm{R \& D} \text { 연구개발인력과 공공 및 민간의 연구개발투자확대를 통해 혁신을 촉진 } \\
\text { 하면서 모든 국가, 특별히 개도국에서의 과학연구와 산업의 기술역량을 강화 }\end{array}$ \\
\hline & & 9.a. & $\begin{array}{l}\text { 아프리카 국가들 특별히 저개발 국가들에 대한 기술지원을 통한 지속가능 인 } \\
\text { 프라 개발 촉진 }\end{array}$ \\
\hline & & 9.b. & $\begin{array}{l}\text { 산업다각화와 부가가치확대를 위한 정책 환경을 조성하는 것을 포함해서 개 } \\
\text { 도국에서의 자국의 기술개발, 연구 및 혁신을 지원 }\end{array}$ \\
\hline & & 9.c. & ICT 기술에 대한 접근성 증대 \\
\hline G10. & 불평등 & - & 없음 \\
\hline G11. & 도시거주환경 & 11.c. & $\begin{array}{l}\text { 저개발국가에 지역의 재료들을 활용한 지속가능하고 유연한 건물들을 짓는데 } \\
\text { 금융적 기술적 지원을 포함한 지원 }\end{array}$ \\
\hline G12. & $\begin{array}{l}\text { 지속가능소비/ } \\
\quad \text { 생산 }\end{array}$ & 12.a. & $\begin{array}{l}\text { 지속가능한 패턴의 소비와 생산이 가능하도록 개도국의 과학기술적 역량을 } \\
\text { 강화하도록 지원 }\end{array}$ \\
\hline
\end{tabular}




\begin{tabular}{|c|c|c|c|}
\hline G13. & $\begin{array}{l}\text { 기후변화 } \\
\text { 영향대응 }\end{array}$ & - & 없음 \\
\hline \multirow[b]{2}{*}{ G14. } & \multirow[b]{2}{*}{ 해양 } & 14.3 & $\begin{array}{l}\text { 모든 수준에서의 과학적 협력 강화를 통해 해양의 산성화 영향을 다루고 최 } \\
\text { 소화 }\end{array}$ \\
\hline & & 14.a. & $\begin{array}{l}\text { IOCCG(Intergovernmental Oceanographic Commission Criteria and } \\
\text { Guidelines) on the Transfer of Marine Technology에 따라서 개도국의 발전 } \\
\text { 에 기여하고 해양의 개선을 위해서 필요한 연구역량의 강화와 해양기술의 이 } \\
\text { 전, 과학적 지식의 증대 }\end{array}$ \\
\hline G15. & $\begin{array}{l}\text { 생태계/산림/ } \\
\text { 사막화/ } \\
\text { 생물다양성 }\end{array}$ & 15.6. & $\begin{array}{l}\text { 유전자 자원들의 할용으로 나오는 유익들을 공정하고 공평하게 나올 수 있도 } \\
\text { 록 하며 이러한 자원들에 대한 적절한 접근성을 촉진할 것 }\end{array}$ \\
\hline G16. & 사회제도/정의 & - & 없음 \\
\hline \multirow{4}{*}{ G17. } & \multirow{4}{*}{$\begin{array}{l}\text { 글로벌 } \\
\text { 파트너십/ } \\
\text { 이행체계 }\end{array}$} & 17.6. & $\begin{array}{l}\text { 북남, 남남, 삼각 협력을 통해서 과학기술혁신에 대한 접근성을 강화하고 UN } \\
\text { 과 글로벌 기술협력강화 체계를 합의하여 상호합의를 통해서 지식의 나눔을 } \\
\text { 강화 }\end{array}$ \\
\hline & & 17.7. & $\begin{array}{l}\text { 환경 친화적 기술들을 개도국에 호혜적인 관점에서 기술개발, 이전, 확산 등을 } \\
\text { 촉진 }\end{array}$ \\
\hline & & 17.8. & $\begin{array}{l}\text { 기술은행의 실행과 저개발국가에 대한 과학기술혁신역량강화 체계를 세우도 } \\
\text { 록 하며 특별히 ICT 등과 같은 enabling technology의 활용을 강화 }\end{array}$ \\
\hline & & 17.16. & $\begin{array}{l}\text { 지속가능발전에 대한 글로벌 파트너십을 강화하면서 다양한 이해관계자들의 } \\
\text { 파트너십을 통해서 지식과 전문성, 기술과 금융재원들을 동원하여 모든 국가 } \\
\text { 들 특별히 개도국의 지속가능발전목표들의 성취를 지지 }\end{array}$ \\
\hline
\end{tabular}

출처: UN (2015) “Sustainable Development Goals”

$\mathrm{UN}$ 개발정상회의(2015)에서의 17 가지 지속가능발전목표들을 살펴보면 경제적, 사회적, 환경적, 평화적 이슈들을 모두 다루고 있으며 과학기술혁신의 관점에 있어서도 경제적 문제, 사회적 문제, 환 경적 문제를 해결하는 과학기술혁신의 역할이 모두 같이 강조될 필요가 있다. 과학기술혁신이 지향하 는 개발협력의 관점에서 관련 목표들을 재정립하여 보면 1) 기업가정신, 친환경적 산업화와 지속가능 한 경제성장을 위한 과학기술혁신과제는 8.2, 8.3, 9.4, 9.5, 9.a., 9.b. 등에 연관된다고 할 수 있다. 2) 물, 에너지, 보건, 생물다양성, 해양 등 글로벌 도전과제에 공동으로 대응하기 위한 과학기술혁신 개발협력의 과제는 6.a., 7.a, 7.b., 3.b., 14.a, 15.6 의 목표와 관련되어 있다고 할 수 있다. 3) 개 도국의 빈곤문제의 해결을 위한 적정기술과 농업/식량 문제의 과학기술혁신 개발협력의 과제는 1.4 , 2.a 목표와 관련되어 있다고 할 수 있다. 마지막으로 이러한 과학기술혁신을 이루기 위한 개발도상국 가의 기반구축으로서의 과학기술혁신 개발협력에 대해서는 $17.6,17.7,17.8$ 의 글로벌 파트너십 구축 
과제에 포함되어 있다고 볼 수 있다.

이러한 관점에서 본다면 과학기술혁신 $\mathrm{ODA}$ 개발협력사업은 1) 친환경적 경제성장과 산업발전을 위한 국가경제적 관점의 개발협력에서의 과학기술혁신 ODA 사업, 2) 기후변화에 따른 물, 에너지, 보건, 생물다양성, 해양 등 다양한 글로벌 도전과제에 대응한 환경적 문제해결을 위한 관점에서의 과 학기술혁신 ODA 사업, 3) 적정기술과 농업/식량 등 빈곤문제와 불평등을 해결하기 위한 사회적 문제 해결관점에서의 과학기술혁신 ODA 사업, 4) 개발도상국가의 과학기술 기반구축을 위한 과학기술혁 신 ODA 사업으로 구분해 볼 수 있다고 할 수 있다.

과학기술혁신 ODA 사업이 이러한 목적지향적인 분류체계를 갖는다고 한다면 과학기술 R\&D 프 로그램에서 가지는 목적지향성과 연계될 가능성을 갖고 있다. 과학기술 혁신시스템에 대한 발전과정 에 있어서도 과학기술혁신이 신기술 산업화를 통한 새로운 부가가치창출과 경제발전에 주목하는 과학 기술혁신 R\&D 프로그램과 국가가 직면하고 있는 환경적 도전과제들과 글로벌 기후변화환경에 대응 하기 위한 환경 R\&D 프로그램, 그리고 사회가 발전하면서 나타나는 사회적 불균형의 이슈와 사회적 문제를 해결하기 위한 사회문제 해결형 R\&D 프로그램 등이 등장하게 되는 것과 맞물린다고 할 수 있 다. 그리고 이러한 경제, 환경, 사회적 이슈 해결을 위한 과학기술 R\&D 프로그램과 더불어 전체 혁신 시스템에 대한 기반구축 인프라 사업이 과학기술혁신전략의 하나라고 할 수 있다. 혁신시스템에 대한 연구는 기존의 과학기술혁신이 선진국을 비롯한 우리나라에서 어떻게 경제적 혁신, 환경적 혁신을 넘 어서 최근에 사회적 혁신(Social Innovation)으로 확산되고 있는지를 지적하고 있으며 이러한 혁신시 스템 연구와 지속가능발전을 위한 과학기술혁신 개발협력 프로그램의 연계는 충분한 협력의 가능성이 높다고 보여진다.

여기서 주목해야할 점은 우리나라를 비롯한 선진국에서는 대부분 경제적 혁신 (산업혁명)과 환경 적 혁신, 사회적 혁신을 순차적으로 과학기술혁신의 관점에서 진행해 오고 있지만 개발도상국가에서 는 지속가능발전을 이루기 위해서 이러한 경제적 혁신, 환경적 혁신, 사회적 혁신을 동시에 진행할 수 있도록 할 수 있겠느냐는 점이다.

그리고 또 하나 더 주목해야 하는 관건은 개발도상국가에서 과연 어떠한 형태의 혁신시스템을 구 축할 것인가에 대한 인식의 공유이다. 국가들의 혁신시스템은 사회적 제도와 맞물려 있어서 어떠한 혁신시스템을 지향하느냐 혹은 강점을 갖고 있느냐에 따라서 사회적 제도와 법제도, 경제관행이 매 우 다르게 발전하기 때문이다. 독일로 대표되는 유럽 대륙국가형 혁신시스템이 사회주의형 경제시스 템으로 노동시장과 시장경쟁제도, 금융시장이 경직적이며 안정적이어서 장기적 혁신, 점진적 혁신시 스템에 맞는 반면에 미국으로 대표되는 영미식 혁신시스템은 창의적 기술발전에 의한 구조조정과 역 동성이 그 특징으로 하고 있어 신기술발전과 신산업창출에 적합한 혁신시스템을 갖고 있기 때문이다. 
이외에도 일본으로 대표되는 아시아 혁신시스템, 남부유럽의 라틴형 혁신시스템, 대표적 복지국가인 북구유럽형 혁신시스템 등 다양한 혁신시스템의 형태를 보이고 있기 때문이다.

따라서 개발도상국들이 처한 역사적 제도적 관점과 국가의 지향점을 보았을 때 어떠한 혁신시스템 을 지향할 것인가는 과학기술혁신 ODA 사업을 추진하는데 있어서 매우 중요한 요소로 작용한다고 할 수 있다. 즉 독일형의 혁신시스템은 장기간의 숙련이 필요한 직업훈련교육과 폴리텍 대학, 정부출연 연구소 제도가 중요한 반면 영미식의 혁신시스템은 창의적인 연구와 다학제적 협력이 중요한 대학원 중심의 산학 협력체계가 중요한 요소로 작용하는 것이다. 결국 해당 개발도상국별로 혁신시스템에 대 한 진단과 특성을 파악하고 국가적 지향점과 더불어 혁신시스템을 설계해나가는 것은 과학기술혁신 $\mathrm{ODA}$ 사업관점에서도 매우 중요한 요소라고 할 수 있다.

개발도상국가들은 기술이전과 기술협력을 활성화할 수 있는 협력체계의 구축에 비상한 관심을 보 이고 있다. UN개발정상회의 지속가능발전목표에 있어서도 '기술은행(Technology Bank)'의 설립과 '기술활성화체계(Technology Facilitation Mechanism)' 설립에 대해서 언급되고 부속서로 자세한 설명이 뒷받침되었으며 이를 위한 남남협력과 삼각협력의 중요성에 대해서 지적하고 있다. 이는 몇 가지 중요한 변화를 암시하고 있는데 개발도상국들이 더 이상 인프라 구축 등 외형적 경제발전의 구 축만이 아니라 지속적인 성장을 이룰 수 있는 과학기술혁신의 기반구축이 중요하다는 점을 인식하고 있다는 점과 중국과 브라질, 인도 등 남남협력의 새로운 개발협력의 공여국들이 늘어나면서 남남협력 을 통한 기술이전과 지식공유의 가능성들이 높아지고 있다는 점이다. 이는 더 이상 기술이전과 지식 공유가 서구 선진국들의 전유물이 아니며 우리나라를 포함한 다양한 신흥공여국들이 개발협력을 통해 서 과학기술혁신의 역량강화를 개발도상국가와 함께 나눌 수 있는 준비가 되어 있다는 점도 시사하고 있는 것이다.

〈표 2〉과기 ODA 사업 현황

\begin{tabular}{l|r|r|r}
\hline \multicolumn{1}{|c|}{ 사업명 } & \multicolumn{1}{|c|}{ '14예산 } & '15예산 & \multicolumn{2}{|c}{ 증감 } \\
\hline 1. 개도국과학기술지원 & 2,150 & 2,860 & 710 \\
• 기관간협력지원 & 950 & 950 & 0 \\
• 적정과학기술 거점센터 지원(현지) & 1,000 & 1,500 & 500 \\
• 지구촌기술나눔센터 지원(국내) & 200 & 410 & 210 \\
\hline
\end{tabular}

출처: 미래창조과학부 (2015) "미래부 ODA 현황" 미래창조과학부 내부자료 
마지막으로 과학기술부문 사업과의 연계성에 대한 고민이 필요하다. 기존 과학기술관련 ODA 사업 가운데 미래창조과학부가 담당하고 있는 사업은 국제기구(UNDP, UN ESCAP, IAEA, ITU 등)에 대 한 분담금 사업과 더불어 양자 차원의 $\mathrm{ODA}$ 사업으로 진행되고 있다. 과학기술 $\mathrm{ODA}$ 는 양자연구개발 협력 및 인력교류사업부터 시작되어 적정과학기술센터를 캄보디아, 라오스, 네팔에 현지설립하면서 본격화되고 있다. 적정기술센터는 현지 대학 등에 공동연구센터를 설립하여 적정기술의 개발에서 상 용화까지를 지원하는 사업으로 진행되고 있다. 이들 사업들은 KOICA가 진행하고자 하는 과학기술혁 신 ODA사업과 연계성이 높으며 이들 거점센터사업들과 개도국협력지원사업의 공동연구 및 인력교류 사업의 확산사업으로서 $\mathrm{KOICA}$ 사업과의 연계성을 공동으로 모색해볼 필요가 있다. 


\section{〈참고문헌〉}

경제인문사회연구회. 2012. “한국형 ODA 모델 수립”. 경제인문사회연구회

교육과학기술부. 2011. "개도국의 역량개발 및 지속가능한 발전을 지원하기 위한 교육과학기

술 공적개발원조 선진화 방안". 교육과학기술부

미래창조과학부. 2015. "미래부 ODA 현황" 미래창조과학부 내부자료. 미래창조과학부

이명진 외. 2014. “글로벌 STI 플랫폼 구축방안”. 과학기술정책연구원 연구보고서. 과학기술 정책연구원

이우성 외. 2010. "아세안지역 지속가능 발전을 위한 과학기술 ODA 협력방안 연구: 캄보디

아, 베트남, 필리핀을 중심으로”. KIEP 연구보고서. 대외경제정책연구원

이우성 외. 2013. "한국형 과학기술 ODA 로드맵”. 미래창조과학부

장용석 외. 2012. “스마트파워 기반 과학기술외교 전략". 과학기술정책연구원 연구보고서. 과

학기술정책연구원

홍성범 외. 2013. "청색경제(Blue Economy)의 부상과 과학기술외교의 효율적 대응전략". 과 학기술정책연구원 연구보고서. 과학기술정책연구원

KOICA. 2015. "Mainstreaming STI in KOICA's ODA". 제29차 개발협력포럼. 한국국제협 력단

UN. 2015. "Sustainable Development Goals". United Nations 